\title{
Políticas linguísticas de Moçambique: controvérsias e perspectivas
}

\author{
Ilídio Macaringue
}

Universidade Pedagógica (UP-Maxixe)

\section{Introdução}

Moçambique localiza-se na costa Sudeste da África e foi colonizado por Portugal. O país tem como língua oficial o Português e alcançou a sua independência a 25 de Junho de 1975, após uma luta armada que decorreu de 1964 a 1974, liderada pela Frente de Libertação de Moçambique (FRELIMO), movimento nacionalista formado pela união de outros três movimentos, nomeadamente União Nacional Africana de Moçambique (MANU), União Democrática Nacional de Moçambique (UDENAMO) e União Nacional Africana para a Independência de Moçambique (UNAMI). Foi com base nesta união que se criaram as premissas mais sólidas para a libertação de Moçambique da dominação portuguesa.

À semelhança dos demais países africanos pós-coloniais, Moçambique herdou uma política linguística e cultural europeia significativa, como consequência do processo de colonização, com particular destaque para área social, econômica, cultural e ideológica, por meio da exploração desenfreada dos recursos naturais, implementação de um sistema educacional diferenciado, hierarquização das pessoas em função das suas funcionalidades e (re) utilizações - a coisificação do Homem. Além disso, são também heranças coloniais as formas diferenciadas de acesso aos bens de consumo e de serviços, à educação, à saúde, ao emprego e à habitação condignas à dignidade humana, aliadas à desestruturação sócio-histórica, cultural, político-administrativa e ao apagamento das línguas e culturas locais tendo em vista a alienação individual e coletiva do povo moçambicano.

É nesse sentido que no processo de construção do Estado-Nação, o país, que outrora combatera o sistema colonialista português e todas as suas práticas imperialistas, viu-se obrigado a adotar as políticas linguísticas do colonizador, uma decisão político-ideológica que visava consolidar o espírito da luta armada de libertação nacional, salvaguardar as conquistas daí decorrentes, gerar o sentimento de unidade (nacional) na diversidade, assegurar e consolidar a integração intra e 
inter-étnica e gerar um ambiente propício à governabilidade do território, o que resultou na neutralização das línguas bantu como línguas francas de ordenamento sociocultural, linguístico e ideológico das populações na perspectiva de, entre outras, matar a tribo para fazer nascer a nação.

E, para tal, era imprescindível massificar o uso da língua portuguesa vista naquele contexto histórico como o único meio auxiliador mais eficaz para (re) produzir semelhanças dentro de um mercado de trocas linguísticas e simbólico heterogêneo e gerar um sentimento de pertencimento à pátria e engajamento na mesma causa nacionalista - a libertação da terra e do Homem do jugo colonial.

Em face destes cenários, neste trabalho, objetivamos analisar o contexto histórico, político-ideológico e sociolinguístico a partir do qual Moçambique adotou as suas políticas linguísticas, tendo em conta a diversidade linguístico-cultural que caracteriza o país e problematizar a sua eficácia decorrente das ambivalências geradas em torno da oficialização do Português Europeu sem o nacionalizar e da nacionalização das línguas autóctones sem as oficializar. Além disso, é também objetivo analisar como a lógica do que está institucionalizado estar a ser subvertida pelas práticas consuetudinárias dos usos da linguagem, o que resulta na nativização e endogeneização do Português Europeu à ecologia da moçambicanidade e, com isso, as línguas bantu reforçam a sua territorialidade e prestígio como meios, também válidos, de cosmovisão do mundo e de construção do Estado-Nação. Metodologicamente, adotamos uma pesquisa qualitativa que, segundo Denzin e Lincoln (2006, p. 17), “consiste em conjunto de práticas materiais e interpretativas que dão visibilidade ao mundo. Essas práticas transformam o mundo em uma série de representações".

É neste contexto que, ao desenvolvermos uma pesquisa qualitativa que se singulariza, entre outros aspectos, por ter "um foco multiparadigmático" em virtude de ela ser cumulativamente "um campo interdisciplinar, transdisciplinar, e às vezes, contradisciplinar que atravessa as humanidades, as ciências sociais, e as ciências físicas", segundo Denzil e Lincoln (op. cit., p. 21), capitalizamos as análises crítico-reflexivas societais e políticas, e estabelecemos conexões teóricas e metateóricas que nos permitem situar a pesquisa como histórica, cultural e pessoal, razão pela qual não é factível dissociar os métodos da pesquisa da ideologia, pois é a partir desta simbiose que se pode construir "diálogos contínuos e de expandir o domínio da deliberação cívica" (Gergen; Gergen, 2006, p. 381).

A pesquisa qualitativa é auxiliada pelos paradigmas interpretativistas pelo fato de eles permitirem inúmeras possibilidades de apreensão e compreensão dos factos e facilitarem a interpretação dos fenômenos sociais situados num contexto 
(Denzin; Lincoln, 2006), até porque "não há como observar o mundo independentemente das práticas sociais e significados vigentes" (Bortoni-Ricardo, 2008, p. 32).

Portanto, a interpretatividade, aliada à reflexividade, descritividade e à introspectividade, enquanto pesquisador que transita entre o cognoscível e o cognoscente, tendo como lócus Moçambique, a partir do olhar do local, constituem alicerces basilares que orientam esta pesquisa baseada num "movimento permanente e incessante de estranhar o familiar e se familiarizar com o estranho" (Velho, 1978; Mata, 1978; 1981 Apud Albuquerque, 2014, p. 62).

Estes movimentos, a partir da Periferia, constituem uma postura epistêmica de fronteira, equivalente ao que Pennycook (2006, p. 74) denomina de Linguística Aplicada Transgressiva na medida em que as transgressões "não somente penetram território proibido, como tentam pensar o que não deveria ser pensado, fazer o que não deveria ser feito", já que, segundo o mesmo autor (ibidem) que cita Jenks (2003), a transgressão é "aquela conduta que destrói as regras e transgride os limites", salientando, porém, que ela não é sinónimo de "desordem ou caos, já que sempre deixa implícita uma ordem que está sendo transgredida". Por isso, ao longo do trabalho desenvolvemos reflexões para entendermos e fazer entender os significados subjacentes a todo o processo histórico, sociolinguístico, cultural e político-ideológico que determinou os caminhos, as escolhas, as incertezas e as contradições em torno das políticas linguísticas de Moçambique.

\section{Contextualização histórica, político-ideológica e sociolinguística de Moçambique}

$\mathrm{O}$ atual território de Moçambique resulta do processo de ocupação efectiva exercida por Portugal, com o "auxílio" de algumas potências europeias e das companhias majestáticas que as delegou poderes para tal, em conformidade com as deliberações saídas da Conferência de Berlim (1884-1885), na qual as potências coloniais europeias dividiram entre si o continente africano e, por consequência, os destinos dos seus povos. É neste sentido que, para compreendermos as políticas linguísticas de Moçambique, afigura-se essencial uma incursão na sua história e na ideologia por detrás da sua libertação e da construção do Estado-Nação.

Ocupado por quase 500 anos por Portugal, aquando da chegada dos primeiros navegadores liderados por Vasco da Gama, em 1498, e formalmente colonizado, de forma efetiva, a partir de 1930, depois de sucessivas lutas de resistência protagonizadas por moçambicanos ao longo do processo histórico de negação à dominação imperialista, o país sucumbiu às políticas segregacionistas do colonizador 
com o objetivo de dividir para reinar e garantir a manutenção e reprodução da dominação.

É neste contexto que, em conformidade com a necessidade de uma presença mais efetiva, Portugal, para além de consolidar os esforços militares para garantir a ocupação e domínio territorial de Moçambique, investiu fortemente na presença da sua máquina administrativa. Com isso, estabeleceu novas fronteiras físicas, jurídicas e simbólicas, destruíndo as anteriormente existentes, com destaque para as simbólicas de matriz étnico-tribal e sociocultural pré-existentes à ocupação e implementou políticas separatistas que hierarquizaram as pessoas de acordo com a cor da sua pele e utilidade nos esforços de colonização.

Assim sendo, a ideologia do Aparelho Administrativo Colonial Português introduzida a partir de 1930, com o "Acto Colonial", deu origem ao Estado Novo em Portugal e preconizou novas diretrizes de exploração das suas colônias, fato que contribuiu para a acentuação das explorações a nível econômico, físico, social, ancestral, antropológico, religioso, cultural, educacional e intelectual e ressignificou novas condutas sociais; status quo, modus vivendi e modus operandi marcadamente deprimentes, fazendo vingar a plenitude da política de dividir para reinar e a reedificação do Homem.

O conceito de ideologia que usamos recorrentemente neste trabalho está em conformidade com a definição de Eagleton (1997, p. 15) como "idéias e crenças que ajudam a legitimar os interesses de um grupo ou classe dominante", razão pela qual estudar a ideologia é estudar as formas de sustentar relações de dominação, pois ela está ao serviço de quem a manipula, sendo que a forma de exercer esse poder passa por perceber os modos a partir dos quais o significado é construído e comunicado por formas simbólicas (Thompson, 2009).

E, para conseguir os seus intentos, Portugal aliou-se à Igreja Católica por meio do acordo denominado Concordata assinado em 1940, o qual estipulou o uso das línguas autóctones nos cultos religiosos e, posteriormente, por volta de 1963, segundo Mazula (1995, p. 88), foi "autorizado o emprego do idioma local como instrumento de ensino da língua portuguesa". É neste quadro que o Estatuto Missionário publicado em 5 de Abril de 1941 conferiu mais poderes à Igreja Católica em Moçambique, tornando-a num aliado privilegiado do Governo Colonial Português na condução de todo o ensino indígena com o fim, segundo Castiano, Ngoenha e Berthoud (2006, p. 27), de "civilizar e nacionalizar o indígena por meio da língua portuguesa e gradual compreensão da doutrina e moral cristã".

Como se pode constatar, o uso das línguas autóctones no ensino e nos cultos religiosos não visava a sua valorização, muito menos das culturas locais por meio delas veiculadas e nem sequer fomentar as aprendizagens de forma eficaz, já que 
o propósito era formar moçambicanos como aprendizes e com baixa educação escolar. Por isso, o objetivo central era permitir que, a partir das suas línguas bantu e das suas culturas, os moçambicanos acedecem à aprendizagem do Português e fossem aculturados lusitanamente. Assim sendo, o uso da doutrina moral cristã católica servia para neutralizar as revoltas e reproduzir um ser humano manso e incorporável à dominação colonial portuguesa.

A partir destes pressupostos, o Português ganhou uma importância particular na medida em que serviu de mecanismo aglutinador das diferenças linguísticas e culturais entre os moçambicanos e os portugueses, o que permitiu a Portugal estratificar dois grupos sociais: os civilizados, também denominados assimilados, que em larga medida serviam de suporte ao Aparelho Administrativo Colonial e os não civilizados, tipificados como indígenas, os deserdados da sua própria terra. Segundo Mazula (1995, p. 100), são considerados indígenas nas respectivas províncias "os indivíduos de raça negra que, nelas tendo nascido ou vivido habitualmente, ainda não possuem a cultura e os hábitos individuais e sociais exigidos pela integral aplicação do direito público e privado dos cidadãos portugueses".

Estes fatos permitem-nos perceber que o ensino e aprendizagem da língua portuguesa constituía, também, um meio ideológico de dividir para reinar, sucedendo ao que Bourdieu (2007, p. 10) chama de produções simbólicas como instrumento de dominação para a legitimação dessas distinções cujo objetivo é a "integração fictícia da sociedade no seu conjunto, portanto, à desmobilização (falsa consciência) das classes dominadas; para a legitimação da ordem estabelecida por meio do estabelecimento das distinções", razão pela qual o autor defende que (op. cit., p. 11), “a cultura que une (intermediário de comunicação) é também a cultura que separa (instrumento de distinção)", tendo em conta que, ao legitimarem-se as distinções, consagra-se o marco hierárquico entre a cultura dominante e a cultura dominada e, com isso, perpetuam-se as correlações de força deixando-se crer que existem culturas e línguas mais importantes que outras.

É por isso mesmo que julgamos que os moçambicanos com capacidade de aprender e falar "correctamente" o Português tornaram-se auxiliares da Administração Colonial, porém sem ocupar cargos de relevância administrativa. Com esta estratégia, Portugal foi, aos poucos, alargando o número de falantes do Português, até porque estava consciente da necessidade da existência de pessoas "aportuguesadas" em Moçambique como forma de garantir o seu domínio aos olhos da comunidade internacional. Em paralelo, os portugueses investiram em larga escala para a expurgação da "identidade cultural dos moçambicanos" com vista a torná-los novos “cidadãos portugueses", contudo, sem gozarem das benesses que tal nacionalidade atribuía, fomentando, deste modo, a falsa consciência no seio 
da população e que mais tarde veio a rebelar-se contra a exploração imperialista e contra todas as formas de aculturação sistemática levadas a cabo pela metrópole.

A aculturação, segundo Cuche (2002, p. 115), é o "conjunto de fenômenos que resultam de um contato contínuo e direto entre grupos de indivíduos de culturas diferentes e que provocam mudanças nos modelos (patterns) culturais iniciais de um ou dos dois grupos" e refere que ela é diferente da assimilação. Portanto, "a assimilação deve ser compreendida como a última fase da aculturação, fase, aliás, raramente atingida. Ela implica o desaparecimento total da cultura de origem de um grupo e na interiorização completa da cultura do grupo dominante" (Cuche, 2002, p. 116). Desta feita, a língua portuguesa foi expandida por meio das escolas com o alicerce da Igreja Católica e, posteriormente, com o apoio das Igrejas Protestantes que também ensinavam a língua inglesa. Com isto, pode-se dizer que à Igreja Católica cabe o mérito, em parte, da massificação do Português, às Igrejas Protestantes do Inglês. É caso para dizer que os católicos idolatraram o Português e os protestantes o Inglês.

O ensino e a aprendizagem do Português em larga escala constituíam, para Portugal, um desiderato patriótico, nacionalista e mercantilista para gerenciar o mercado das trocas linguísticas e também como um mecanismo de domínio social, ideológico, econômico, político, cultural e simbólico dos moçambicanos. Para além disso, visava responder, de forma firme, ao avanço vertiginoso da aprendizagem do Inglês por parte de moçambicanos que almejavam trabalhar nas minas sul-africanas, mal necessário, já que entre Portugal e a África do Sul existia um acordo de fornecimento de mão-de-obra, negócio muito rentável para os cofres da metrópole.

Apesar de todos os esforços, a dominação portuguesa sofreu revés por conta do grupo dos assimilados e de outros compatriotas nacionalistas no território nacional e na diáspora que, impulsionados pelo contato de línguas e culturas, e também pelos movimentos de libertação nacional que levaram alguns países africanos a alcançarem as suas independências a partir da década de 1960, ampliaram o seu ângulo de cosmovisão do mundo e, com isso, uma nova forma de estar, de ser, de sentir, de ver e de fazer na sociedade que os despertou das crueldades a que o povo fora submetido.

Foi uma etapa de nova (re)orientação que permitiu a "limpeza psicológica" dos vestígios do colonialismo, sobretudo aqueles que foram considerados maléficos, porque o objetivo do discurso colonial, segundo Bhabha (1998, p. 111), era de "apresentar o colonizado como uma população de tipos degenerados com base na origem racial de modo a justificar a conquista e estabelecer sistema de administração e instrução". A este respeito, Fanon (2005) refere que o colonialismo não se 
satisfaz em prender o povo nas suas redes, em esvaziar o cérebro do colonizado com o recurso à opressão de toda forma e de todo o conteúdo, e defende que

a cultura, que é arrancada do passado para ser desdobrada em todo o seu esplendor, não é a do seu país. O colonialismo, que não matizou os seus esforços, que não deixou de afirmar que o negro é um selvagem e o negro, para ele, não era nem angolano nem nigeriano. Ele falava a língua negra (Fanon, 2005, p. 244-245).

A tomada de uma nova consciência por uma parte dos moçambicanos, cuja negritude é bem descrita por Fanon, foi expressa, por exemplo, com o recurso à denúncia dos males do colonialismo nos jornais e a formação de movimentos cívicos e políticos contra a presença colonial, fato que originou a desculturação que, segundo Cuche (2002), ocorre quando os povos se manifestam contrários aos valores impostos.

Este pensamento conecta-se ao de Hall (2009) ao referir que a relação colonização e pós-colonização está sujeita, irrevogavelmente, a um campo de poder-saber e a partir do momento em que se verifica o deslocamento do foco das relações que caracterizam o colonializador e o colonizado, este último torna-se dono do seu próprio destino e desenvolve a capacidade de criticar e desconstruir as representações ideológicas até então vigentes com vista a traçar novos rumos orientadores, razão pela qual, para Freire (2006), o oprimido tem o opressor dentro de si.

Com base nisso, na construção dos alicerces do Estado-Nação, primeiro no seio dos grupos de guerrilheiros, políticos e simpatizantes filiados à FRELIMO no interior do território nacional e na diáspora, e depois nas zonas libertadas, onde se plantou a semente da governação pós-colonial, e após a proclamação da independência nacional, o Estado Moçambicano expurgou da herança colonial os seus malefícios e adotou os aspectos positivos que lhe serviam de base para a construção e consolidação do Estado Nacional, nomeadamente as políticas linguísticas que vigoravam até então.

Para o efeito, o Estado adotou uma série de políticas concertadas que visavam promover, quer por meio da língua(gem), entendida como um caleidoscópio por ser multifacetada e dinâmica (César; Cavalcanti, 2007), quer por meio da cultura definida por Canclini $(2009$, p. 41) como "conjunto dos processos sociais de significação ou, de um modo mais complexo, a cultura abarca o conjunto de processos sociais de produção, circulação e consumo da significação na vida social", a produção e reprodução da violação simbólica nos termos de Bourdieu (2007) como construção da realidade para estabelecer uma ordem gnoseológica assente na promoção da falsa consciência. 
Assim sendo, a língua(gem) e a cultura ligadas à representação conceituada por Goffman (1975, p. 29) como a "atividade de um indivíduo que se passa num período caracterizado por sua presença contínua diante de um grupo particular de observadores e que tem sobre estes alguma influência" e à identidade vista de forma não essencialista, já que as pessoas são portadoras de inúmeras e complexas identidades e que as manifestam em função dos contextos (Hall 2000; Silva, 2000) constituem, por excelência, um mecanismo de exercício do poder simbólico na medida em que criam uma ilusão óptica e gnoseológica de que todas as pessoas têm a mesma identidade e a mesma cultura no território do Estado-Nação e basta arregimentá-las por uma língua comum e que se considere língua de Estado para gerar sentimento de pertencimento ao território do Estado Nacional, na tentativa de visibilizar a nação e silenciar a tribo e o etnicismo, vistos como males que atentam contra a unidade nacional.

Com isso, a língua oficial é erigida de dogmas e veneração o que faz com que, na visão ideológica do Estado-Nação, tenha de ser reproduzida como se fosse cópia em carbono da norma em uso, razão pela qual se legitima a norma e promove-se o seu uso na sociedade sem se levar em consideração que uma norma linguística é uma hipóstase e como tal sujeita às dinâmicas sociais e históricas, até porque, conforme sustenta Back (1987), a língua é um espelho da cultura e como tal ela deve ser diferente, de uma cultura à outra, facto que também subverte a lógica ideológica por detrás da construção dos Estados Nacionais assente na trilogia um povo, uma língua e uma cultura, facto que não passa, segundo Geertz (1989), de uma utopia, uma esperança alimentada pelas tradições inventadas (Hobsbawn, 1984).

No entanto, apesar de tudo isso, interessa à política do Estado-Nação disseminar estas ideologias, crenças e ritualizações, pois as "culturas nacionais são sistemas de representações" (SARUP, 1996, p. 152). Por isso, as identidades únicas e fixas no território do Estado-Nação são uma crença, uma construção sociossimbólica do que é política e ideologicamente ideal, pelo que não passa de um estereótipo, segundo Bhabha (1998), até porque "nenhuma sociedade consiste unicamente de excêntricos anônimos que se tocam e ricocheteiam como bolas de bilhar" (Geertz, 2008, p. 99).

É neste quadro que Lopes (2004, p. 21), que cita Machel (1979), refere que "a necessidade de combatermos o opressor exigia um combate intransigente contra o tribalismo e o regionalismo. Foi esta necessidade de unidade que nos impôs que a única língua comum - a que servia para oprimir - assumisse uma nova dimensão", consagrando-se assim a herança tácita da política linguística do período colonial e adaptada para o período pós-colonial. Com a independência nacional, 
novos valores culturais e ideológicos foram colocados em prática, e é neste contexto que o país adota o Português como língua oficial e de unidade nacional, tendo em vista consolidar os propósitos da construção do Estado-Nação assentes na homogeneização linguística e cultural.

\section{A construção do estado-nação em Moçambique: (re) avaliando alguns pressupostos}

A ideia de moçambicanidade não está dissociada das representações que estão por detrás da construção do Estado-Nação. Por isso, a construção do Estado-Nação em Moçambique é um processo contínuo e permanente, visto que Estado e Nação são duas categorias que estão intimamente ligadas ao nacionalismo, compondo facetas da mesma moeda quando falamos do processo de formação de um Estado Nacional, pois "o nacionalismo não é o despertar das nações para a autoconsciência: ele inventa nações onde elas não existem” (Anderson, 2008, p. 32).

Por isso, Bauer (1996, p. 81) defende que "a nação apresenta-se como um modelo natural, e o Estado um produto artificial. [...]. O Estado, portanto, deve seguir a nação e uni-la politicamente". Ainda de acordo com Bauer (op. cit.), a nação tem um carácter nacional. Todavia, tal carácter não significa que haja uma comunhão, a priori, pré-estabelecida. Pelo contrário, existe um esforço para se estabelecer a comunhão, mesmo reconhecendo-se as diferenças individuais e grupais, pelo que "nação é comumente entendida como a totalidade dos cidadãos do Estado, ou a totalidade dos habitantes de um espaço econômico" (Bauer, 1996. p. 76).

A este propósito, Weber (1994, p. 72) defende que a nação não é simétrica a uma comunidade linguística e defende que "a nação, no uso linguístico habitual, não é idêntica ao povo de um Estado", até porque no mesmo Estado podem existir várias nações, fato que também caracteriza Moçambique, visto que ela é, acima de tudo, uma construção simbólica que decorre de sentimentos, expectativas, esperanças, pertencimento e adesão, por vezes obrigatória, a uma colectividade com a qual se pode compartilhar um passado comum, valores históricos, sociais, culturais, ou sofrimento suscetíveis de serem intelegíveis.

Por essa razão, uma pessoa pode pertencer a múltiplas e variadas nações no interior do seu país, porém cabe à política ideológica e hegemônica do Estado Nacional perseguir estes sentimentos, por vezes dispersos e fragmentados, condensá-los na mesma base de harmonização colectiva e reproduzir a hegemonia conducente à mesma jurisdição do território no qual vegetam estes sentimentos para integrá-los ao exercício da soberania do Estado.

Segundo Hall (2006, p. 62), a etnia é um termo que se usa para referir às características culturais, tais como língua, religião, costume e tradições, e aponta 
que "essa crença acaba, no mundo moderno, por ser um mito. A Europa Ocidental não tem qualquer nação que seja composta de apenas um único povo, uma única cultura ou etnia. As nações modernas são, todas, híbridos culturais". O mesmo autor (op. cit. p. 62-63) enfatiza também que "é ainda mais difícil unificar a identidade nacional em torno de uma raça. [...] A raça não é uma categoria biológica ou genética que tenha qualquer validade científica. [...]. A raça é uma categoria discursiva e não uma categoria biológica”.

Com a ideia de que a nação não se funda unicamente por pressupostos étnicos e nem raciais, uma vez que a raça não explica, por exemplo, que o ser branco ariano significa ser alemão, ou então que ser negro é ser africano, até porque existem em África Estados cuja população é maioritariamente branca, como são os casos do Egito, Tunísia, Líbia e Argélia, que fazem parte da denominada “África Branca", Renan (1997) coloca em causa o mito de formação das nações com base na raça e na língua ao defender que "as línguas são formações históricas que indicam pouco sobre o sangue dos que as falam e que, em todo o caso, não poderiam agrilhoar a liberdade humana de escolher a família com a qual deseja unir-se para a vida e para a morte" (Renan, 1997, p. 169-170).

Ainda no mesmo diapasão, Bauer (1996, p. 45) refere que "os ingleses e irlandeses, os dinamarqueses e noruegueses, os sérvios e os croatas, falam, em cada um dos casos, a mesma língua, e nem por isso são um único povo. Os judeus, por outro lado, não têm uma língua comum mas são uma nação”. A propósito da impossibilidade de qualificar sentimentos de pertença tomando a língua como base para a formação de uma nação, Hobsbawn (1990, p. 75) faz a seguinte consideração: “o que sabemos é que lutas nacionalistas foram agravadas algumas vezes, nos tempos modernos, pela recusa de frações de grupos lingüísticos em aceitar a unidade política com outros que falam a mesma língua". Weber (1994, p. 173), no mesmo sentido, refere que os "alsacianos de língua alemã que rejeitam a pertinência à ‘nação' alemã não se consideram, por isso, simples membros da 'nação' francesa'.

Assim sendo, afigura-se pouco consistente a percepção de algumas correntes de opinião de que Moçambique não é uma nação devido à sua diversidade ético-linguística que se traduz nas acentuadas assimetrias e heterogeneidades para a formação da coletividade, até porque a nação é um sentimento de pertença que não está diretamente indexado a questões étnicas, raciais, culturais, linguísticas e um dos seus sustentáculos é o sofrimento e o desejo de as pessoas alcançarem objetivos comuns, o que justifica o fato de inúmeros e diversificados grupos étnico-linguísticos e culturais se terem unido e superado as suas divergências estruturantes, em decorrência do sofrimento imposto pela colonização, em torno do mesmo movimento nacionalista para libertar o país. 
Por isso, corroboramos com Hobsbawn (1990) ao analisar as inferências a partir das quais se podem determinar as bases para a constituição de uma nação, nomeadamente: associação histórica com um Estado de passado recente e razoavelmente durável; existência de uma elite cultural longamente estabelecida que possuísse um vernáculo administrativo e literário escrito e uma provada capacidade de conquista. Neste sentido, segundo Renan (1997, p. 173), "uma nação é, portanto, uma grande solidariedade, constituída pelo sentimento dos sacrifícios que se fizeram e que ainda se fariam. Ela supõe um passado, mas se resume no presente a um fato tangível: o consenso, o desejo claramente expresso de continuar a vida em comum", ou seja, como advoga Anderson (2008, p. 32), a nação é "uma comunidade política imaginada - e imaginada como sendo intrinsecamente limitada, e ao mesmo tempo soberana", pois a "a coletividade é vivenciada e os símbolos são representados como algo separado dos indivíduos em questão, algo superior e mais sagrado do que eles" (Elias, 1997, p. 143).

Desta feita, entendemos que o sentimento de pertença à genérica nação moçambicana vingou independentemente da etnia - vários grupos de diferentes origens lutaram para libertar as terras conquistadas pelos portugueses; da raça - houve casos de brancos europeus que auxiliaram os moçambicanos (negros e brancos) na luta contra o colonialismo português; da religião - católicos, muçulmanos, protestantes e ateus resistiram à ocupação europeia; da língua - pessoas de diferentes idiomas juntaram-se na luta de libertação nacional, pensamento que ecoa em Machel (1983, p. 20) ao defender que "a nação identifica-se pelos seus símbolos. Perante a história, perante a cultura, perante a nação não há católicos, não há muçulmanos, não há protestantes, não há ateus - há moçambicanos patriotas ou antipatriotas". Este fato é também testemunhado em Mondlane ao defender que

O movimento nacionalista não surgiu numa comunidade estável, historicamente com uma unidade linguística, territorial, económica e cultural. Em Moçambique foi a dominação colonial que deu origem à comunidade territorial e criou as bases para uma coerência psicológica fundada na experiência da descriminação, exploração, trabalho forçado, e outros aspectos de dominação colonial (Mondlane, 1995, p.87).

É neste sentido que a moçambicanidade se forma a partir da política de homogeneização da diversidade linguística e cultural da FRELIMO forjada nos tempos de luta armada de libertação nacional preconizada na filosofia política de Eduardo Mondlane e de Samora Machel, ícones do nacionalismo moçambicano, visto que o primeiro é considerado o arquiteto da unidade nacional por ter contribuído, com a sua visão de totalidadade, na união dos principais movimentos nacionalistas de luta pela independência num único movimento libertador; o segundo por ser 
considerado o pai da nacionalidade moçambicana, ao ter declarado a independência do país e por ter sido um dos principais ideólogos da construção de um Estado-Nação indexado aos princípios de 'Homem Novo'.

Com base nessas políticas, o Estado Moçambicano, por meio da FRELIMO, já que praticamente não existiam fronteiras entre o Estado e o partido do governo, realidade expressa na primeira Constituição da República de 1975 (revista em 1990 e em 2004) no artigo terceiro ao referir-se que "A República Popular de Moçambique é orientada pela linha política definida pela FRELIMO, que é a força dirigente do Estado e da Sociedade", enveredou por um sistema de governação socialista e comunista de base marxista e leninista, programando a vida da sociedade, arregimentando e complexificando ainda mais o sistema de violação simbólica, promovendo uma educação escolar de (re)produção de semelhanças e apagamento de diferenças para sustentar a ideia de um Estado-Nação uno e indivisível sustentado na moçambicanidade, estereótipo representativo de base homogeneizante da diversidade linguística, cultural e de identidade que caracteriza Moçambique.

É a moçambicanidade que faz existir a ideia de nacionalidade, do nacionalismo e de pertença a uma coletividade do Estado, uma vez que gera o sentimento de gnoseologia e de partilha de valores comuns. Ainda que sentida como essência e forma, a moçambicanidade não passa de uma construção filosófica e simbólica alicerçada em representações que cosntituem a identidade nacional. Ainda assim, ela não é estática. Pelo contrário, é dinâmica, processual, controversa e em constantes crises como qualquer outra identidade e processa-se como mecanismo de negação a todo o tipo de alienação colonial e, ao mesmo tempo, como afirmação e auto-definição das categorias socioculturais e simbólico-ideológicas que definem o que é ser um cidadão moçambicano, ou seja, a moçambicanidade é a negação à portugalidade.

Portanto, a moçambicanidade, como projeto político-ideológico, nasce da resistência e da negação da portugalidade e funda-se na base da "representatividade" sociocultural e étnico-linguística da diversidade do país em estereótipos ideológicos e revigora-se a partir da ideia de que é possível arregimentar as pessoas no território do Estado-Nação recorrendo-se às amálgamas representacionais das formas de ser, de estar, de pensar, de sentir, de agir e de fazer, concomitantes à construção e (re)produção de semelhanças num mercado de trocas linguísticas e simbólicas.

Com a filosofia de (re)produção em larga escala de semelhanças para consolidar a moçambicanidade, o Estado-Nação em Moçambique aprofundou o seu emparelhamento ideológico e com isso a mediatização das suas políticas estruturantes 
da territorialização do poder, isto é, disseminar em massa e à escala nacional os fundamentos do Homem Novo, a ideia de várias culturas de base única - moçambicana, fato que se enquadra no posicionamento de Fanon (2005), quando analisa o papel dos movimentos independentistas em África, ao defender que combater pela cultura nacional é combater pela libertação da nação, já que não existe um combate cultural que se desenvolva literalmente ao combate popular.

\section{As faces e interfaces das políticas linguísticas de Moçambique}

No contexto da formação dos Estados Nacionais, cada país adota as suas políticas linguísticas em função dos objetivos que pretende alcançar, o que faz da política linguística e da planificação linguística dois complementos importantes na materialização das políticas públicas dos Estados tendo em conta as implicações político-ideológicas a partir das quais se estrutura todo o processo de desenvolvimento. Neste sentido, partimos do mote lançado por Bourdieu (2008, p. 31) segundo o qual "os linguistas incorporam à teoria um objeto pré-construído cujas leis sociais de construção esquecem e cuja génese social em todo o caso mascaram" e defende que não é o espaço que determina a língua, pelo contrário, é a língua que define o seu espaço.

Segundo Calvet (1987), citado por Fiorin (2009, p. 15), política linguística é um "conjunto de escolhas conscientes efectuadas no domínio das relações entre língua e vida social, e mais particularmente entre língua e vida nacional”. E porque a existência de uma política linguística pressupõe, a priori, a existência de uma planificação linguística, Fiorin (ibidem) define-a como "a busca e o emprego dos meios necessários para a aplicação de uma política linguística", o que nos leva a concluir que a primeira implica, necessariamente, a existência da segunda, pois é o seu instrumento materializador, porém o inverso não procede. Em Moçambique, o contexto político-ideológico da escolha da língua portuguesa como língua oficial, língua de Estado e língua de unidade nacional, a partir da qual se estruturam as ações do Estado Nacional é ancorada na seguinte passagem de Ganhão (1979) citado por Lopes (2004)

\footnotetext{
A decisão de se optar pela língua portuguesa, como língua oficial na República Popular de Moçambique, foi uma decisão política meditada e ponderada visando atingir um objectivo - a preservação da unidade nacional e integridade do território. A história da apropriação da língua portuguesa, como factor de unidade, nivelador das diferenças veio desde a criação da Frelimo em 1962 (Lopes, 2004, p. 21).
}

Como se pode constatar, a escolha, não linguística, mas política, é herança de uma política linguística implementada pela própria FRELIMO durante a luta armada. Produto de um território caracterizado pela diversidade social, linguística, 
étnica e cultural, a FRELIMO, desde cedo, adotou, no seu seio, uma política linguística de emancipação do Português como língua de comunicação tendo em vista a neutralizar divisionismos intra e inter-étnicos de base tribal, pois a orientação era clara: matar a tribo para fazer nascer a nação e, como tal, era necessário reproduzir semelhanças de pertencimento da mesma terra de acolhimento, já que não se lutava pela terra pré-chegada dos portugueses visto que as fronteiras foram desarticuladas pelas dinâmicas da ocupação das potências imperialistas.

Com isso, a escolha da norma europeia como padrão em Moçambique foi decorrente das contingências de uma realidade específica: a diversidade linguística constituía um entrave para os propósitos da consolidação do jovem Estado-Nação na visão político-ideológica, como também para a materialização das políticas públicas para o desenvolvimento que não deviam descurar o emparelhamento de todas as sensibilidades étnico-linguísticas e culturais num sistema nacional para gerar e consolidar o Estado Nacional e combater as assimetrias regionais que poderiam atentar contra a unidade nacional e a soberania do Estado.

É neste contexto que a língua portuguesa se torna num elemento sine qua non para a estruturação ideológica da população, por meio da política da formação do Homem Novo, tipificado como aquele que defende a política da FRELIMO e reconhece nela o poder de guia supremo do Estado e do povo; combate o regionalismo, o tribalismo, o individualismo e o obscurantismo; tem um espírito de sacrifício pela pátria. Um 'Homem Novo' capaz de se adequar à nova ordem social, política, econômica, religiosa, ideológica, enfim, construir um 'Homem Novo' capaz de fazer face aos desafios da construção do Estado Nacional, razão pela qual "a imposição da língua legítima contra os idiomas e os dialetos faz parte das estratégias políticas destinadas a assegurar a eternização das conquistas da Revolução pela produção e reprodução do homem novo" (Bourdieu, 2008, p. 34).

Com isso, e de forma equivocada, mas intencional, as línguas autóctoes, num total de 19, segundo Firmino (2001) - ainda que reconheçamos que existem números díspares a este respeito, porém não nos iremos deter neste aspecto -, foram neutralizadas e silenciadas, pois para a lógica ideológica a sua existência atentava contra a unidade nacional e a construção de um Estado-Nação uno e indivisível, situação que gerou dissonância no seio da FRELIMO, uma vez que havia certos círculos de opinião que não viam com bons olhos a crescente subalternização das línguas autóctones tendo em conta o seu papel importante na consciencialização da sociedade, por exemplo, na estruturação e ramificação das relações intra-familiares, inter-culturais, inter-étnicas e intra-étnicas e na moralização da população.

É por essa razão que Mazula (1995) aponta que, em 1982, no contexto de ideias liberais no seio da FRELIMO, e no âmbito do IV Congresso, é que se 
reconheceu a diversidade cultural como riqueza nacional, abrindo-se as portas para o início do estudo e da necessidade de valorização das línguas autóctones, ainda que reconheçamos que muito ainda falta por se fazer. Como se pode constatar, as políticas linguísticas de Moçambique estão associadas ao processo de construção e consolidação do Estado-Nação razão pela qual corroboramos com Bourdieu (2008, p. 32) ao referir que "a língua oficial está enredada com o Estado tanto em sua gênese, como em seus usos. É no processo de construção do Estado que se criam as condições de constituição de um mercado linguístico unificado e dominado pela língua oficial”.

Dessa forma, Moçambique, como a generalidade dos países africanos, viu-se obrigado a herdar parte significativa das políticas linguísticas que o colonialismo implementara no país como forma de sustentar a ideia de unidade na diversidade e garantir a governabilidade do território a partir da (re) produção de semelhanças concomitantes ao povo da mesma nação tendo em vista a implementação das políticas públicas para o desenvolvimento. Esta escolha, que resultou de um metabolismo político-ideológico no seio da própria FRELIMO, já que combatera o colonialismo, porém acabou por herdar algumas das suas práticas, como é o caso das políticas linguísticas, justificou-se, de entre outras, pelas seguintes razões: a) impossibilidade de unificar a diversidade linguístico-cultural a partir de uma língua autóctone; b) tentativa de unificar na diversidade, contornando possíveis levantamentos intra- e inter-étnicos de insubordinação e que atentassem contra a soberania e a consolidação do Estado-Nação em caso de escolha de uma língua autóctone como língua oficial; c) inexistência de línguas autóctones mais representativas à escala nacional; d) incapacidade do Estado Nacional vencer a ideologia neocolonialista.

É diante deste cenário que com a proclamação da independência nacional de Moçambique, a 25 de Junho de 1975, também se proclama e outorga-se o novo estatuto funcional da língua portuguesa, língua do antigo colonizador que, com a retomada da soberania do território, passa a ser, também, legitimada como língua de Moçambique e dos moçambicanos, e mecanismo a partir do qual se deve pensar e construir-se a unidade nacional na diversidade. Essa apropriação do português decorreu, também, do desejo do Estado-Nação de afirmação da sua legitimidade e de empoderamento dos seus diversificados usos na extensão territorial, facto que procede na análise seguinte de Rosário (1982) ao defender que

Diferentemente de muitos países do continente, a situação da língua portuguesa não é a de uma herança incómoda com carácter provisório enquanto se não encontra uma língua 'genuinamente' africana. [...]. É um projecto que visa anular todas as consequências da arbitrariedade do traçado geográfico do País, dar-lhe uma identidade nacional e uma consciência cultural, através do povo que nele habita (Rosário, 1982, p. 64-65). 
Curiosamente, apesar de a FRELIMO ter escolhido o Português como língua oficial, tal estatuto não foi expresso formalmente na primeira Constituição da República Popular de Moçambique de 1975², facto que viria acontecer na Constituição da República de 1990, aprovada no dia 2 de Novembro e entrou em vigor no dia 30 do mesmo mês e do mesmo ano. O estatuto do Português, nesta constituição, foi clarificado de forma equivocada. No artigo $5^{\circ}$, ponto 1 , prescreve-se que "Na República de Moçambique a língua portuguesa é a língua oficial" e não se atribui a ela, de forma clara, o papel prescrito para as línguas autóctones conforme se estipula, no mesmo artigo, no ponto 2, que "O Estado valoriza as línguas nacionais e promove o seu desenvolvimento e utilização como línguas veiculares e na educação dos cidadãos".

Esta situação deixa certas ambivalências pelo facto de, à língua portuguesa, ter-se conferido o estatuto de língua oficial e deixar-se a descoberto a sua restritividade decorrente da ênfase do papel que se atribuiu às línguas denominadas nacionais como veiculares e de educação dos cidadãos - como se o Português não o fosse e não desempenhasse também tal papel. Já na atual Constituição da República que foi aprovada em 16 de Novembro de 2004 e entrou em vigor em 21 de Janeiro de 2005, prescreve-se, no artigo $9^{\circ}$, que "o Estado valoriza as línguas nacionais como património cultural e educacional e promove o seu desenvolvimento e utilização crescente como línguas veiculares da nossa identidade" e no artigo $10^{\circ}$ que "na República de Moçambique a língua portuguesa é a língua oficial".

Mais uma vez, nesta Constituição, percebe-se outro equívoco das políticas linguísticas preconizadas pelo Estado Moçambicano pelo facto de se dar ênfase às línguas nacionais como veiculadoras da identidade nacional, deixando-se transparecer uma falsa lógica de que o que se veicula a partir do Português não é identidade nacional. Afinal, ela é a língua oficial e, por conseguinte, o símbolo mais abrangente e aglutinador da política ideológica da construção do Estado-Nação. Olhando para a Lei 6/92, de 6 de Maio de 1992 (lei que regula o funcionamento do Sistema Nacional de Educação - SNE), no artigo $4^{\circ}$, determina-se o dever de "valorizar e desenvolver as línguas nacionais, promovendo a sua introdução progressiva na educação dos cidadãos", aclarando-se, mais uma vez, a preocupação do Estado na disseminação dessas línguas.

Assim sendo, o Português é considerado língua oficial e, por conseguinte, meio de uso em fóruns oficiais e as línguas autóctones são consideradas línguas nacionais, patrimônio cultural e educacional e o Estado promove o seu desenvolvimento

1. Cf. O Boletim da República, n. ${ }^{\circ}$ 1, I série, de 6 de Julho de 1974 e publicado na revista Tempo, n. ${ }^{\circ} 248$. Desde a mudança da Constituição de 1975 para a de 1990, o país passou de República Popular de Moçambique para República de Moçambique. 
e utilização crescente como línguas veiculares da identidade moçambicana, facto que não deixa de ser curioso visto que no texto constitucional não se reconhece à língua portuguesa, de forma explícita, o estatuto de patrimônio cultural e educacional apesar de ser a língua de ensino no país, e muito menos como veiculadora da identidade nacional, naturalizando-se uma ideia, a nosso ver, errônea de que é cultura nacional o que provém apenas das línguas autóctones e escamoteia-se uma realidade presente na sociedade - a existência de muitos moçambicanos cujo repertório sociocultural está intimamente ligado à língua portuguesa e é a partir dela que transmitem culturas e identidades também nacionais.

Apesar de oficialmente determinarem-se os papéis e os estatutos das línguas em Moçambique, algo importante não nos passou despercebido. O Português é considerado língua oficial e também língua de unidade nacional, apesar de esta última tipificação não estar expressa na Constituição da República e isso decorre da crença de que por meio dela pode-se gerir e aglutinar-se a diversidade linguístico-cultural que caracteriza o país e forjar-se uma pretensa identidade nacional unificadora. Porém, a LP, que é um símbolo nacional, língua de Estado, língua da nacionalidade moçambicana, um meio de comunicação importante no contexto da diversidade que caracteriza o país e língua veicular dos desígnios da pátria e do Estado não é considerada, oficialmente, uma língua nacional nem sequer língua estrangeira, abrindo-se uma ambivalência sobre a sua tipificação em termos de origem ou de acolhimento, o que não coloca em causa a sua funcionalidade multifacetada e prestígio social, apesar de ser a língua segunda de quase todo o universo populacional.

Às línguas autóctones reservou-se o estatuto de línguas nacionais, o que não deixa de ser curioso, pois elas não têm expressividade nacional, ou seja, abrangência nacional e fragmentam-se por alguns territórios localizados. Mais ainda, são consideradas nacionais, mas o seu uso é restritivo nos fóruns oficiais e na vida nacional. Por isso, Firmino (2006) refere que

esta política linguística oficializou o Português sem o nacionalizar, e nacionalizou as línguas autóctones, sem as oficializar. Como resultado, a actual política linguística não está em conformidade, nem simbólica, nem instrumental com a natureza da diversidade linguística que caracteriza Moçambique (Firmino, 2006, p. 182).

Vistas as coisas neste prisma, o Português, sendo a língua de abrangência nacional deveria, também, ser denominado como uma língua nacional em razão da sua apropriação linguística, simbólica, cultural e ideológica pelos moçambicanos e porque é suposto que seja falado em todo o país tendo em conta que é língua oficial. Mais ainda, a sua nacionalização justifica-se pelo fato de que o Português 
Europeu, que é a língua oficial, estar pouco enraizada e de pouco domínio público e porque nem sempre existe intelegibilidade entre a norma europeia e a realidade consuetudinária de Moçambique, resultando daí lexemas e construções léxico-sintáticas, léxico-semânticas, morfossintáticas e morfológicas à margem do que está prescrito na norma.

Por conseguinte, em Moçambique, falam-se várias línguas portuguesas sob denominação genérica de Português de Moçambique, que é outra língua portuguesa que resulta da apropriação e nativização da norma europeia e torna-se língua dos moçambicanos e legitimada pelo contexto sociocultural, sociolinguístico, sociossimbólico e ideológico dos usos da língua. Apesar do prestígio e massificação dos usos do Português, também se verifica um movimento, ainda que pouco sistematizado, mas consolidado, de valorização das línguas autóctones no cenário sociolinguístico e cultural moçambicano para atender ao clamor nacional de "preservação" destas línguas.

Neste contexto, assinalamos o fato de altos dignitários do Estado recorrerem ao uso das suas línguas bantu em comícios populares com as populações; o uso de lexemas bantu em discursos e cerimônias oficiais; o aumento do número de gramáticas e de dicionários destas línguas; a existência de cursos superiores do nível de licenciatura e de mestrado na Universidade Eduardo Mondlane e na Universidade Pedagógica; a formação de professores nos magistérios nestas línguas; existência de programas na rádio e na televisão, com o destaque para a Rádio Moçambique e a Televisão de Moçambique, respectivamente emissoras públicas; o movimento cada vez mais crescente de escritores, escultores, músicos, pintores e outros artistas que recorrem sistematicamente ao uso de lexemas de origem bantu nas suas produções artísticas.

A estes exemplos, junta-se o movimento crescente que pretende retomar alguns topônimos de origem bantu que, pela força da colonização portuguesa, tinham sido suprimidos ou então aportuguesados. $\mathrm{O}$ caso mais evidente aconteceu na capital do país, Maputo, com a mudança da nomenclatura dos distritos municipais. Com efeito, Maxaquene passou para KaMaxaquene, Inhaca para KaNhaca e Catembe para KaTembe. Foi ainda na capital moçambicana que, no ano 2000, a Assembleia Municipal adotou o Xironga como uma das línguas de trabalho, a par do Português.

Desta feita, é lícito afirmarmos que a política linguística de Moçambique ainda está em construção, pelo que existe a necessidade de se desenvolver esforços para que as fissuras que resultaram da imposição de uma língua minoritária sejam finalmente sepultadas e que o país se revigore dentro da sua diversidade linguística e cultural através da (re)padronização da língua portuguesa, uma vez que 
o processo de nacionalização traz subsídios que demonstram que o Português falado pela maioria está na contra-mão da norma europeia, daí ser outra língua portuguesa.

A este respeito, trazemos um diálogo atemporal e ontológico de matriz filosófica entre três ilustres do mundo lusófono. O poeta português Fernando Pessoa dizia já nos seus tempos logínquos que "a minha pátria é a língua portuguesa" (Pessoa, 1982, p. 17). Já Mia Couto, escritor contemporâneo moçambicano, defende que "a minha língua portuguesa, repito a minha língua portuguesa, é a pátria que estou inventando para mim" (Couto, 2011, p. 186). E para aflorar ainda mais as hostes, José Saramago, escritor português e Prémio Nobel da Literatura, num pronunciamento proferido no documentário "Línguas - Vidas em Português" dirigido pelo moçambicano Víctor Lopes que reside no Brasil toma um posicionamento discursivo performativo de cariz democrático ao defender que "não há uma língua portuguesa, há línguas em português".

Assim sendo, percebemos, seja no pensamento de Fernando Pessoa, seja no de Mia Couto, que a língua portuguesa é um meio de manifestação do patriotismo, do nacionalismo e da nacionalidade que se entrelaçam na pretensa identidade do país de onde o falante é proveniente, razão pela qual, a priori, espera-se que um cidadão português fale o Português Europeu, o moçambicano fale Português de Moçambique, assim sucessivamente nos demais países lusófonos. Já em José Saramago desmistifica-se a ideia de uma língua portuguesa hegemônica e rebate-se a pretensão da paternidade lusitana do Português ao defender-se a existência de várias línguas em Português, democratizando-se e legitimando-se o seu uso como línguas e não dialectos ou variedades.

Em função de todos os aspectos arrolados ao longo deste capítulo, um ponto de ordem, para a reflexão sobre as políticas linguísticas de Moçambique se impõe, fundada no questionamento, que se diga bem perspicaz, do linguista brasileiro Celso Cunha: Será admissível a hipótese de que Portugal nos cedeu a utilização do idioma e, por isso, dele deve ter para sempre o controlo normativo? E como que a colocar o dedo na ferida, ressaltando a soberania dos usos do Português pelo mundo afora onde se fala esta língua, o mesmo autor defende que "a capital da língua portuguesa estará onde estiver o meridiano da cultura" (Cunha, 1975, 47), deixando bem claro que o Português é patrimônio de todos os falantes legitimados pela sua apropriação e não única e exclusivamente dos portugueses.

2. O documentário foi produzido em 2004 sob o patrocínio do Brasil e de Portugal. Disponível em: http:// www.youtube.com/watch?feature=player_embedded\&v=Git8MwRqDcE. Acesso em: 21 de Abril de 2014. 


\section{Conclusão}

Neste capítulo, propusemo-nos a analisar o contexto histórico, político-ideológico e sociolinguístico a partir do qual Moçambique adotou as suas políticas linguísticas tendo em conta a diversidade linguístico-cultural que caracteriza o país, bem como problematizar a eficácia das actuais políticas linguísticas em vigor. Assim sendo, aferimos que a escolha do Português, numa primeira fase como língua de unidade nacional para gerar unidade na diversidade no seio do movimento de libertação nacional, FRELIMO, e posteriormente como língua oficial após a independência nacional resultou de uma decisão política e não linguística, cujo objetivo central era neutralizar a influência das línguas autóctones que consolidavam, na visão ideológica da libertação e da construção do Estado-Nação, as vivências tribais, pelo que era necessário matar a tribo para construir e consolidar a nação e o Estado-Nação.

Com isso, o Estado Moçambicano, por meio da FRELIMO, que herdara as políticas linguísticas do colonialismo português, implementou na letra e no espírito uma campanha sistematizada de neutralização das línguas autóctones e promoveu o Português ao estatuto de língua oficial e de unidade nacional de forma tácita, na tentativa de, entre outras, semear um mercado de reprodução de estereótipos homegêneos, o que permeou uma série de consequências na legitimação das ditas línguas nacionais, fato que contribui, até hoje, na crise de prestígio das mesmas, não obstante os esforços para atenuar os estragos que tais políticas causaram na sociedade.

Das análises feitas, percebemos ainda que a situação sociolinguística atual de Moçambique vulgariza os fundamentos das políticas linguísticas tendo em conta que cresce, de modo vertiginoso, o número de falantes que não falam a norma europeia, colocando-se em causa a vitalidade de um princípio normativo minorizado pelo direito costumeiro, tendo em consideração que a legislação determina um modelo de falar e os usos consuetudinários da língua outro modelo, consagrando-se um processo dicotômico entre o ideal perfeito assente na norma como referência inclusiva e não "exclusiva" e o real perfeito fundamentado nas normas comuns. Com issso, a língua que une é também a língua que separa e fragmenta a sociedade.

Por isso, a língua portuguesa em Moçambique está a seguir um rumo próprio que se consubstancia numa língua híbrida, endogeneizada à ecologia local; outra língua portuguesa, criando-se assim pressupostos que nos permitem asseverar que a mudança linguística em relação à norma europeia é um processo irreversível e que deverá acarretar novos reajustes nas políticas linguísticas do país. E para tal, é preciso que se reconheça que o Português de Moçambique, que é amálgama dos 
diversos falares da língua portuguesa no país, é uma língua legítima e que deve ser ancorada legalmente como língua oficial a partir de uma reforma nas políticas linguísticas do Estado Moçambicano, à semelhança do que ocorre com o Brasil que tem o Português do Brasil como sua língua oficial.

\section{Referências}

Albuquerque, José Lindomar C. Limites e paradoxos da cidadania no territorio fronteirico: O atendimento dos brasiguaios no sistema público de saude em Foz do Iguaçu (Brasil). Geopolítica(s), v.3, nº 2, p.185-205, 2012.

Albuquerque, José Lindomar C. A dinâmica das fronteiras: os brasiguaios na fronteira entre o Brasil e o Paraguai. São Paulo: Annablume, 2010.

Anderson, Benedict. Comunidades imaginadas. São Paulo: Companhia das letras, 2008.

Back, Eurico. Fracasso do ensino de Português: proposta de solução. Petrópolis: Vozes, 1987.

Bauer, Otto. A nação. In: Balakrishnan, Gopal (Org.). Um mapa da questão nacional. Rio de Janeiro: Contraponto Editora, 1996.

Bhabha, Homi K. O local da cultura. Belo Horizonte: Ed.UFMG, 1998.

Bourdieu, Pierre. A economia das trocas linguísticas. 2. ed. São Paulo: EDUSP, 2008.

Bourdieu, Pierre. O poder simbólico. 4. ed. Rio de Janeiro: Editora Bertrand Brasil, 2007.

Bortoni-Ricardo, Stella M. O professor pesquisador: introdução à pesquisa qualitativa. São Paulo: Parábola Editorial, 2008.

Canclini, Néstor G. Diferentes, desiguais e desconectados. Rio de Janeiro: UFRJ, 2009.

Castiano, José P.; Ngoenha, Severino E.; Berthoud, Gerald. A longa marcha duma Educação para Todos em Moçambique. 2. ed. Maputo: Imprensa Universitária, 2006.

César, América. L.; Cavalcanti, Marilda do Couto. Do singular para o multifacetado: o conceito de língua como caleidoscópio. In: Cavalcanti, Marilda C.; Bortoni-Ricardo, Stella M. (Org.). Transculturalidade, linguagem e educação. Campinas: Mercado de Letras, 2007. p. 45-66.

Couto, Mia. E se Obama fosse africano? e outras interinvenções. 2. reimp. São Paulo: Companhia das Letras, 2011.

Cuche, Dennys. A noção de cultura nas ciências sociais. 2. ed. Bauru: EDUSC, 2002.

Cunha, Celso. Uma politica do idioma. 3. ed. Rio de Janeiro: Tempo Brasileiro, 1975.

Denzin, Norman K. ; Lincoln, Yvonna S. O sétimo momento: deixando o passado para trás. In: Denzin, Norman K. ; Lincoln, Yvonna S (Org.). O planejamento da pesquisa qualitativa: teorias e abordagens. 2. ed. Porto Alegre: Artmed, 2006. p. 389-405.

Eagleton, Terry. Ideologia. São Paulo: Ed. UNESP, Editora Boitempo, 1997.

Elias, Norbert. Uma digressão sobre o nacionalismo. Os alemães: a luta pelo poder e a evolução do habitus nos séculos XIX e XX. Rio de Janeiro: Jorge Zahar Editor, 1997.

Fanon, Frantz. Os condenados da terra. Juiz de Fora: Ed. UFJF, 2005. 
Fiorin, José Luiz. O acordo ortográfico: uma questão de política linguística. Veredas v.1, n.9. Juíz de Fora, p.7-9, 2009.

Firmino, Gregório. A "Questão linguística” na Africa pós-colonial: o caso do Português e das línguas autóctones em Moçambique. Maputo: Texto Editores, 2006.

Firmino, Gregório. Situação linguística de Moçambique. Dados do II recenseamento geral da população e habitação de 1997. Maputo: INE, 2001.

Freire, Paulo. Pedagogia do oprimido. Rio de Janeiro: Edições Paz e Terra, 2006.

Gergen, Mary M; Gergen, Kenneth J. Investigação qualitativa: tensões e transformações. In: Denzin, Norman K.; Lincoln, Yvonna S. (Org.). O planejamento da pesquisa qualitativa: teorias e abordagens. 2.ed. Porto Alegre: Artmed, 2006. p. 367-387.

Geertz, Clifford. A interpretação das culturas. Rio de Janeiro: LTC Editora, 1989.

Geertz, Clifford. O saber local: novos ensaios em atropologia interpretativa. 10.ed. Petrópolis: Vozes, 2008.

Goffman, Erving. A representação do eu na vida cotidiana. Petrópolis: Vozes, 1975.

Hall, Stuart. Quem precisa da identidade? In: Silva, Tomaz Tadeu da. (Org.). Identidade e diferença: a perspectiva dos estudos culturais. Petrópolis: Vozes, 2000. p. 103-133.

Hall, Stuart. A identidade cultural na pós-modernidade. 11. ed. Rio de Janeiro: DP\&A Editora, 2006

Hall, Stuart. Da diáspora. Identidades e mediações culturais. Belo Horizonte: Ed.UFMG, 2009.

Hobsbawn, Eric. Nações e nacionalismo desde 1780. Rio de Janeiro: Paz e Terra, 1990.

Lopes, Armando Jorge. A batalha das línguas: perspectivas sobre linguística aplicada em Moçambique. Maputo: Imprensa Universitária, 2004.

Machel, Samora. Consolidemos aquilo que nos une. Reunião da direção do Partido e do Estado com os representantes das confissões religiosas. 14 a 17 de Dezembro, 1982. Coleção Unidade Nacinal. Maputo: INLD, 1983.

Mazula, Brazão. Educação, cultura e ideologia em Moçambique. Maputo: Edições Afrontamento e Fundo Bibliográfico da Língua Portuguesa, 1995.

Mondlane, Eduardo. Lutar por Moçambique. Maputo: CEA, 1995.

Moçambique. Imprensa Nacional. Boletim da República, n. ${ }^{\circ}$ 1, I série publicado em 6 de Julho de 1974.

Moçambique. Constituição da República Popular de Moçambique de 1975. Maputo: Imprensa Nacional, 1975.

Moçambique. Constituição da República Popular de Moçambique de 1990. Maputo: Imprensa Nacional, 1990.

Moçambique. Lei 6/92 de 6 de Maio de 1992. Maputo: Imprensa Nacional, 1992.

Moçambique. Constituição da República de Moçambique. Maputo: Imprensa Nacional, 2004.

Pennycook, Alastair. Uma linguística aplicada transgressiva. In: Moita Lopes, Luiz Paulo da (Org.). Por uma linguística aplicada indisciplinar. São Paulo: Parábola Editorial, 2006. p. 67-84. 
Renan, Ernest. O que é uma nação? Trad. Samuel Titan Jr. Revista de Ciencias Sociais/USP: Plural, Sociologia. v.4, p.154-175, $1^{\circ}$ sem, São Paulo: USP, 1997.

Rosário, Lourenço. Língua Portuguesa e cultura moçambicana: de instrumento de consciência e unidade nacional a veículo e expressão de identidade cultural. Cadernos de Literatura. Coimbra: CLPUC, 1982.

Sarup, Madan. Identify: culture and the postmoder world. Endiburg: University Press, 1996.

Silva, Tomaz Tadeu da. Identidade e diferenças: a perspectiva dos estudos culturais. Petrópolis: Vozes, 2000.

Thompson, Jhon B. Ideologia e cultura moderna: teoria social crítica na era dos meios de comunicação de massa. 8. ed. Petrópolis: Vozes, 2009.

Weber, Max. Comunidade política: economia e sociedade. 3. ed. Brasília: Ed.UnB, 1994. 